\title{
Editorial
}

\section{Walk the Talk: Open Access and Academic Libraries}

Driven to near despair by the ever increasing cost of scholarship, particularly the growing expense of scientific journal subscriptions, Mary Case and I, way back in 1998, wrote an article for Notices of the American Mathematical Society with the highfalutin title of "Reforming Scholarly Publishing in the Sciences." In it we argued that scientists, working with librarians and professional societies, needed to keep their scholarship within the "circle of the academy" so that we could fully exploit "the archival and distribution potential of new digital information technology." We were trying to find new ways of doing business in scholarly publishing, and we were not alone in thinking about this. Just a year before, the Association of Research Libraries created SPARC (Scholarly Publishing and Academic Resources Coalition) whose mission was to be a catalyst for the creation of a more competitive marketplace for scholarly publishing and to be an advocate for fair and ethical uses of scholarship.

Back then the concept of "open access" as a new way of doing business was hardly on anyone's radar, but in the ensuing decade, SPARC and a dedicated group of scholars, librarians, and even some publishers rallied around the practice of making scholarship freely available over the Internet. Peter Suber has been tireless in documenting the growth and development of the open access movement through his Open Access News blog (which ceased recently, a victim of its own success) and the SPARC Open Access Newsletter. ACRL (Association of College and Research Libraries), the publisher of this journal, has seen its Scholarly Communications Committee become an active and effective supporter of open access and scholarly publishing reform through its successful institutes, toolkit, and the marketing of the Create Change Web site.

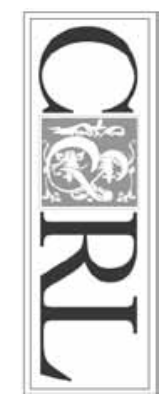

Today, The Directory of Open Access Journals lists almost five thousand open access journals in operation. The publishers represented there have created open access business models for themselves, often looking to research funders or institutions rather than to subscribers to bear the cost of publication. Also, many traditional for-profit and nonprofit publishers are turning "green," allowing their authors to post copies of their articles in institutional and disciplinary open access repositories. Major government agencies such as the US National Institutes of Health, influential foundations including the Wellcome Trust and Howard Hughes Medical Institute, and leading universities exemplified by Harvard University now mandate open access publication from their clients and faculty.

Reform in scholarly publishing has made remarkable strides. Our call in the late 1990's and others like it were heeded, action was taken, and now more scholarship is taking full advantage of the open and broad distribution afforded by the Internet.

But not so fast and self-congratulatory. There is still much to do. The openness of the science disciplines is quite varied. While you can find physics literature readily and freely available, you would be hard pressed to do deep research in chemistry without access to a library or research center with deep pockets that can provide online access to expensive proprietary databases. And what about our own discipline: our own journals and knowledge assets in library and information science?

Three recent studies published in $\mathrm{Col}$ lege $\mathcal{E}$ Research Libraries give us some trou- 
bling as well as encouraging indicators.

Last year, in the July 2009 issue, we brought you "Where There's a Will There's a Way?: Survey of Academic Librarian Attitudes About Open Access." Based on a national study of academic librarians conducted in 2006, the authorsKristi Palmer, Emily Dill, and Charlene Christie-found a "discrepancy between stated support of library involvement in open access initiatives and significantly lacking action toward this end." In our current issue, Doug Way in "The Open Access Availability of Library and Information Science Literature" reports that his research using Google Scholar to search for open accessibility of top LIS journal literature shows "the archiving of articles is not a regular practice in the field, articles are not being deposited in institutional or subject repositories at a high rate and the overall percentage of available open access articles in LIS was similar to the findings in previous studies."
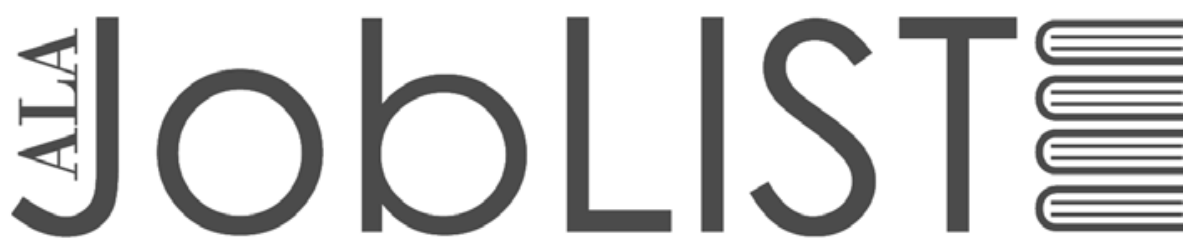

The \#1 source for jobs in Library and Information Science and Technology

\section{WHERE JOB SEEKERS AND EMPLOYERS GET RESULTS}
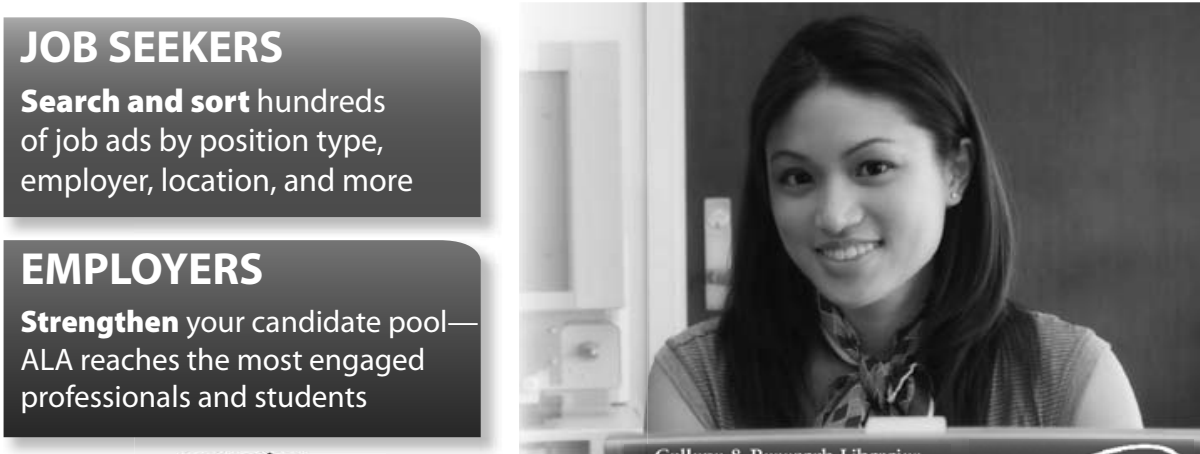

ALA libraries HRDR neny ACRL joblist.ala.org 